\title{
FAKTOR-FAKTOR YANG MEMPENGARUHI PENERIMAAN PAJAK REKLAME DENGAN PDRB SEBAGAI VARIABEL MODERATING DI KABUPATEN MAGETAN
}

\author{
Dina Dwi Fitriana ${ }^{1}$, M. Agus Sudrajat ${ }^{2}$ \\ dinadf@gmail.com \\ agussudrajat84@gmail.com \\ Universitas PGRI Madiun
}

\begin{abstract}
This study aims to determine the effect of the population, the number of industries and the number of SIUP on advertisement tax acceptance. And, to know the influence of these variables with PDRB as a moderation variable. The population in this study is the population, the number of industries, and the number of SIUP every year. Sampling in this research using Purposive Sampling. The number of samples in this study as much as 6 years. Hypothesis testing using multiple linear regression analysis. The result of the research shows that: (1) Partially, the number of population has no significant positive effect on advertisement tax acceptance, the variable of the number of industries has a significant positive effect on advertisement tax acceptance, and SIUP amount negatively affect advertisement tax acceptance. (2) GRDP weaken the relation of population to advertisement tax acceptance, PDRB also weaken the correlation of industry amount to advertisement tax acceptance, and PDRB strengthen the relation of SIUP amount to advertisement tax revenue. Keywords: Number of Population, Number of Industry, Number of SIUP, GRDP, Advertising Tax.
\end{abstract}

\begin{abstract}
ABSTRAK
Penelitian ini bertujuan untuk mengetahui pengaruh jumlah penduduk, jumlah industri dan jumlah SIUP terhadap penerimaan pajak reklame. Serta, untuk mengetahui pengaruh dari variabel tersebut dengan PDRB sebagai variable moderasi. Populasi dalam penelitian ini adalah jumlah penduduk, jumlah industri, dan jumlah SIUP setiap tahun. Pengambilan sampel dalam penelitian ini menggunakan Purposive Sampling. Jumlah sampel dalam penelitian ini sebanyak 6 tahun. Pengujian hipotesis menggunakan analisis regresi linier berganda. Hasil penelitian menunjukkan bahwa: (1) Secara Parsial Jumlah penduduk tidak berpengaruh positif signifikan terhadap penerimaan pajak reklame, variabel jumlah industri berpengaruh positif signifikan terhadap penerimaan pajak reklame, dan jumlah SIUP berpengaruh negatif terhadap penerimaan pajak reklame. (2) PDRB memperlemah hubungan jumlah penduduk terhadap penerimaan pajak reklame, PDRB juga memperlemah hubungan jumlah industri terhadap penerimaan pajak reklame, dan PDRB memperkuat hubungan jumlah SIUP terhadap penerimaan pajak reklame.
\end{abstract}

Kata kunci: Jumlah Penduduk, Jumlah Industri, Jumlah SIUP, PDRB, Pajak Reklame.

\section{PENDAHULUAN}

Pelaksanaan pemerintahan dan pembangunan daerah tidak lepas dari peranan Pendapatan Asli Daerah (PAD) sebagai salah satu sumber penerimaan daerah. Penerimaan PAD berasal dari Pendapatan Pajak Daerah, Hasil Retribusi Daerah, Hasil Pengelolaan Kekayaan Daerah yang Dipisahkan dan Lain-lain
Pendapatan Asli Daerah yang Sah. Dalam Undang-Undang Nomor 28 Tahun 2009 tentang Pajak Daerah dan Retribusi Daerah dijelaskan bahwa Pajak Daerah adalah kontribusi wajib pajak kepada Daerah yang terutang oleh orang pribadi atau badan yang bersifat memaksa berdasarkan Undang-Undang, dengan tidak mendapatkan imbalan secara langsung dan 
digunakan untuk keperluan daerah bagi sebesar-besarnya kemakmuran rakyat (Fitriandi, Aryanto \& Priyono, 2016).

Tabel 1.1 Rata-Rata Kontribusi PajakPajak Daerah Terhadap PAD di Kabupaten Magetan Tahun 2011-2016

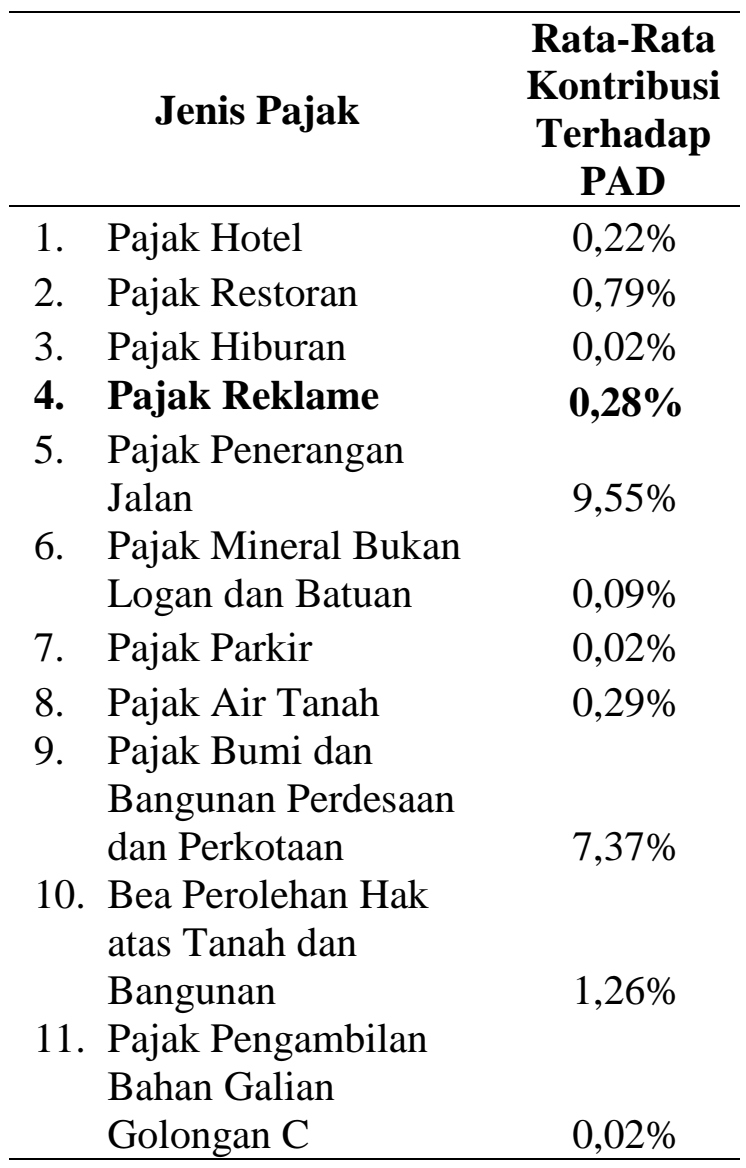

Sumber: BPS Kabupaten Magetan (Data Diolah) Salah satu penyumbang kontribusi atas penerimaan pajak berasal dari Pajak Reklame. Pajak Reklame menurut Undang-undang Nomor 28 Tahun 2007 dalam Fitriandi, Aryanto dan Priyono (2016) adalah pajak atas penyelenggaraan reklame, dimana reklame adalah benda, alat, perbuatan, atau media yang bentuk dan corak ragamnya dirancang untuk tujuan komersial memperkenalkan, menganjurkan, mempromosikan, atau untuk menarik perhatian umum terhadap barang, jasa, orang, atau badan, yang dapat dilihat, dibaca, didengar, dirasakan, dan/atau dinikmati oleh umum.

Rata-rata realisasi penerimaan pajak reklame tahun 2011-2016 masih relatif kecil dibanding jenis pajak lain dalam penerimaan pajak daerah seperti yang terlihat pada Tabel 1.1. Hal ini membuktikan bahwa pajak reklame bukan merupakan pajak unggulan di Kabupaten Magetan. Meskipun bukan merupakan pajak unggulan, pajak reklame juga tidak bisa dipandang sebelah mata karena ada beberapa jenis pajak yang realisasi penerimaannya lebih sedikit dari pada pajak reklame. Yang membuat pajak reklame menarik untuk diteliti adalah dengan melihat kenyataan di lapangan reklame banyak ditemukan di tempattempat umum namun kontribusinya terhadap PAD masih relatif kecil.

Tujuan penelitian ini adalah untuk memberikan bukti empiris pengaruh jumlah penduduk, jumlah industri dan jumlah SIUP terhadap penerimaan pajak reklame secara parsial serta untuk memberikan bukti empiris pengaruh jumlah penduduk, jumlah industri dan jumlah SIUP yang dimoderasi oleh PDRB terhadap penerimaan pajak reklame

\section{KAJIAN PUSTAKA DAN HIPOTESIS PENELITIAN}

\section{A. Kajian Pustaka}

\section{Teori Fischer}

Teori Fischer dalam Yogyandaru dan Sumantri (2013) mengatakan bahwa ada tiga dasar basis pemungutan pajak pusat dan daerah. Dasar basis pemungutan berdasarkan pendapat Fischer meliputi pajak daerah maupun pusat yang berbasis pada pendapatan dan perusahaan (income and corporate), konsumsi (comsumption), dan kekayaan (wealth).

Kaitannya dengan penerimaan pajak reklame yang berbasis pada konsumsi, maka secara otomatis setiap konsumsi yang berkaitan dengan transaksi penjualan suatu barang/jasa yang merupakan basis atau objek pajak reklame akan meningkatkan penerimaan pajak reklame itu 
sendiri. Dalam penelitian ini yang digunakan sebagai indikator untuk mengetahui pertumbuhan penerimaan pajak reklame adalah tenaga kerja, yang meliputi penduduk sebagai pelaku usaha, industri sebagai jenis usaha, dan SIUP sebagai cerminan kegiatan usaha, sedangkan PDRB mencerminkan total nilai tambah yang diciptakan oleh seluruh sektor atau kegiatan ekonomi pada kurun waktu tertentu.

\section{Pajak Reklame}

Pajak Reklame menurut Undang-Undang Nomor 28 tahun 2009 dalam Fitriandi, Aryanto dan Priyono (2016) adalah pajak atas penyelenggaraan reklame dimana reklame adalah benda, alat, perbuatan, atau media yang bentuk dan corak ragamnya dirancang untuk tujuan komersial memperkenalkan, menganjurkan, mempromosikan, atau untuk menarik perhatian umum terhadap barang, jasa, orang, atau badan, yang dapat dilihat, dibaca, didengar, dirasakan, dan/atau dinikmati oleh umum.

\section{Jumlah Penduduk}

Menurut
Suhadak dan Hidayat (2015)
penduduk adalah sejumlah orang
yang tinggal secara menetap pada
suatu daerah dalam jangka waktu
yang lama. Berdasar pada teori
konsumsi rumah tangga,
konsumsi akan meningkat apabila
jumlah penduduk meningkat.
Banyaknya jumlah penduduk
akan memacu kegiatan produksi,
konsumsi dari penduduk inilah
yang akan menimbulkan
permintaan agregat (Seetharam
dalam Putri, 2013: 195). Pada
akhirnya, peningkatan konsumsi
agregat memungkinkan usaha-
usaha produktif berkembang,

begitu pula perekonomian secara keseluruhan.

\section{Jumlah Industri}

Jumlah industri adalah jumlah usaha industri baik industri kecil, menengah, maupun besar (Tristianto, 2015: 3). Jumlah industri merupakan salah satu faktor positif pemicu pertumbuhan ekonomi. Jumlah industri yang menggunakan jasa pemasangan reklame juga berpengaruh terhadap penerimaan pajak reklame. Bertambahnya jumlah industri yang memasang reklame mengakibatkan objek pajak bertambah luas, sehingga penerimaan daerah pun meningkat (Yogyandaru dan Sumantri, 2013).

5. Jumlah Surat Ijin Usaha Perdagangan (SIUP)

Menurut Putri (2013: 196-197) jumlah pembuatan Surat Ijin Usaha Perdagangan (SIUP) yang diperoleh suatu daerah mencerminkan banyaknya kegiatan usaha baik di bidang perdagangan maupun jasa yang didirikan di daerah tersebut. Semakin banyak kegiatan usaha yang didirikan, maka terdapat kemungkinan peningkatan bagi para pendiri usaha untuk menggunakan jasa reklame dalam mempromosikan barang atau jasa yang mereka produksi, yang pada selanjutnya akan meningkatkan penerimaan pajak reklame.

\section{Produk Domestik Regional Bruto (PDRB)}

Menurut Tristianto, Arisman dan Fajriana (2013) Produk Domestik Regional Bruto (PDRB) adalah jumlah nilai tambah yang dihasilkan dari seluruh unit usaha di suatu wilayah, atau merupakan jumlah semua nilai barang/jasa akhir yang dihasilkan oleh seuruh unit 
ekonomi di suatu wilayah. Produk Domestik Regional Bruto berfungsi untuk indikator ekonomi yang memuat berbagai unsur ekonomi yang di dalamnya tertampak dengan jelas keadaan ekonomi secara menyeluruh dalam suatu daerah dengan pertumbuhan ekonominya, pendapatan per kapita serta berbagai unsur lainnya. Di mana dengan data-data tersebut dapat membantu pengambilan keputusan dalam perencanaan serta evaluasi sehingga pembangunan akan terealisasi sesuai tujuannya.

\section{B. Kerangka Berpikir}

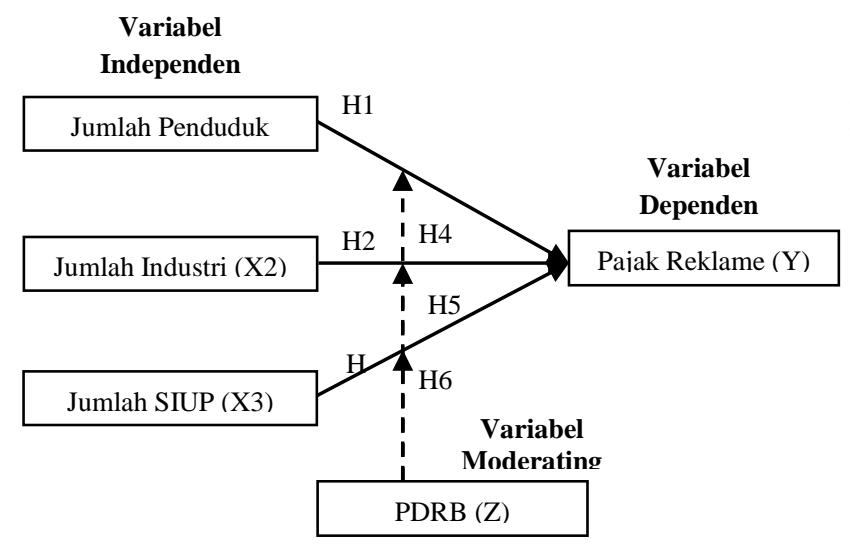

Gambar 2.1. Kerangka Berfikir

\section{METODE PENELITIAN}

Penelitian ini menggunakan pendekatan kuantitatif dilihat dari jenis data yang bersifat angka dengan Jumlah Penduduk (X1), Jumlah Industri (X2), Jumlah Siup (X3) sebagai variabel independen, Penerimaan Pajak Reklame (Y) sebagai variabel dependen, dan PDRB (Z) sebagai variabel moderating. Data yang digunakan dalam peneliti ini adalah data sekunder selama enam tahun yaitu 2011-2016. Pengambilan sampel dilakukan dengan metode purposive sampling. Secara sederhana, purposive sampling berarti teknik pengambilan sampel secara sengaja. Maksudnya peneliti menentukan sendiri sampel yang diambil. Jadi, sampel diambil dan ditentukan sendiri oleh peneliti (Yogyandaru dan Sumantri, 2013).

Pengumpulan data dilakukan dengan dokumentasi, yaitu data jumlah penduduk, jumlah industri, PDRB, dan data penerimaan pajak reklame yang bersumber dari Badan Pusat Statistik (BPS) Kabupaten Magetan, sedangkan jumlah SIUP bersumber dari Dinas Penanaman Modal dan Pelayanan Terpadu Satu Pintu/Kantor Pelayanan Pajak Terpadu (KPPT) Kabupaten Magetan. Pengumpulan data dilakukan dengan studi pustaka dari buku-buku, laporan penelitian, buletin, jurnal ilmiah, dan penerbitan lainnya yang relevan dengan penelitian ini.

\section{HASIL PENELITIAN DAN PEMBAHASAN}

1. Pengaruh Jumlah Penduduk terhadap Penerimaan Pajak Reklame

Tidak berpengaruhnya jumlah penduduk terhadap penerimaan pajak reklame dikarenakan kenaikan jumlah penduduk tidak sebanding dengan penerimaan pajak reklame. Hal ini dapat dijelaskan bahwa tidak semua penduduk merupakan wajib pajak reklame, hanya orang-orang yang mempunyai usaha/perusahaan atau badan yang berkepentingan saja yang menyelenggarakan reklame. Sehingga dapat disimpulakan bahwa jumlah penduduk yang banyak belum tentu dapat meningkatkan penerimaan pajak daerah terutama pajak reklame.

2. Pengaruh Jumlah Industri terhadap Penerimaan Pajak Reklame

$$
\text { Jumlah industri }
$$

berpengaruh positif signifikan terhadap penerimaan pajak reklame, artinya adanya pertumbuhan jumlah industri akan menaikkan pendapatan pajak reklame. Dengan adanya pertumbuhan jumlah industri yang menggunakan jasa pemasangan 
reklame untuk memasarkan produknya, maka semakin meningkat pula pajak reklame yang diterima.

3. Pengaruh Jumlah SIUP terhadap Penerimaan Pajak Reklame

Dalam penelitian ini jumlah SIUP berpengaruh negatif signifikan terhadap penerimaan pajak reklame, artinya semakin banyak SIUP yang dikeluarkan akan menurunkan minat pelaku usaha untuk menggunakan jasa pemasangan reklame. Menurut Sukirno (2012: 192) tujuan perusahaan adalah mencapai keuntungan yang maksimum. Usaha memaksimumkan keuntungan dapat dicapai dengan cara yang dari sudut pandang ekonomi dipandang sebagai cara yang paling efisien. Secara umum tujuan perusahaan adalah memaksimalkan laba yang diperoleh dengan meningkatkan penjualan dan meminimalkan beban/biaya atau pengeluaran perusahaan (Utomo, 1999: 30). Biaya promosi yang dapat dikurangkan sebagai pengurang Penghasilan Kena Pajak adalah biaya iklan, papan reklame, dan sebagainya yang didukung dengan bukti-bukti (Muljono \& Wicaksono, 2009: 211).

4. Pengaruh Jumlah Penduduk terhadap Penerimaan Pajak Reklame dengan Moderasi PDRB

Tidak berpengaruhnya jumlah penduduk yang dimoderasi PDRB terhadap penerimaan pajak reklame dikarenakan kenaikan jumlah penduduk tidak sebanding dengan penerimaan pajak reklame. Jumlah penduduk yang tinggi tidak berarti penerimaan pajak akan meningkat karena tidak semua penduduk merupakan Wajib Pajak (Fatah, Suhadak dan Hidayat, 2015). Wajib Pajak Reklame adalah orang pribadi atau badan yang menyelenggarakan reklame (Siahaan dalam Liberty, 2013).

PDRB akan lebih tepat jika menjadi variabel independen daripada variabel moderasi, karena PDRB merupakan jumlah dan jasa akhir yang dihasilkan oleh suatu perekonomian dalam satu tahun dan dinyatakan dalam harga konstan. PDRB merupakan ukuran yang sifatnya global, dan bukan merupakan alat ukur pertumbuhan ekonomi yang tepat, karena belum mencerminkan kesejahteraan yang dinikmati oleh setiap penduduk di negara atau daerah yang bersangkutan (Liberty, 2013).

PDRB justru memperlemah hubungan jumlah penduduk dengan penerimaan pajak reklame. Artinya semakin tinggi nilai interaksi antara jumlah penduduk dan PDRB, maka semakin rendah hubungan jumlah penduduk terhadap penerimaan pajak reklame.

5. Pengaruh Jumlah Industri terhadap Penerimaan Pajak Reklame dengan Moderasi PDRB

Jumlah industri yang dimoderasi PDRB tidak berpengaruh negatif signifikan terhadap penerimaan pajak reklame dan PDRB memperlemah hubungan jumlah industri terhadap penerimaan pajak reklame. Hal ini dapat dijelaskan bahwa sebagian besar masyarakat sudah mengetahui keberadaan industri dan produk yang dihasilkan oleh industri sedang dan besar ini, sehingga indutri tersebut tidak perlu lagi untuk mempromosikan produknya melalui reklame (Prasetyo, Masitoh dan Dewi, 2017). Jika industri ini tetap menggunakan media reklame, justru akan meningkatkan biaya iklan yang seharusnya tidak perlu dikeluarkan.

PDRB disini justru memperlemah hubungan jumlah industri terhadap penerimaan pajak reklame. Artinya semakin tinggi nilai interaksi antara jumlah industri dengan PDRB semakin rendah hubungan jumlah industri terhadap penerimaan pajak reklame. 
6. Pengaruh Jumlah SIUP terhadap Penerimaan Pajak Reklame dengan Moderasi PDRB

$\begin{array}{lrr}\text { Jumlah } & \text { SIUP yang } \\ \text { dimoderasi } & \text { PDRB } & \text { berpengaruh }\end{array}$
negatif signifikan terhadap penerimaan pajak reklame dan PDRB memperkuat hubungan jumlah SIUP terhadap penerimaan pajak reklame. Secara umum tujuan suatu perusahaan adalah memaksimalkan laba yang diperoleh dengan cara meningkatkan penjualan dan meminimalkan beban/biaya atau pengeluaran perusahaan (Utomo, 1999: 30). Biaya promosi yang dapat dikurangkan sebagai pengurang Penghasilan Kena Pajak adalah biaya iklan, papan reklame, dan sebagainya yang didukung dengan bukti-bukti (Muljono \& Wicaksono, 2009: 211).

Hal ini dapat dijelaskan bahwa sebuah perusahaan akan mencapai laba maksimal jika biaya yang dikeluarkan semakin sedikit, sehingga perusahaan harus mengorbankan salah satu pengeluaran yang dianggap kurang perlu dalam peningkatan laba perusahaan. Biaya yang mungkin dikeluarkan adalah biaya promosi/biaya reklame, dikarenakan sebagian besar masyarakat sudah mengetahui keberadaan perusahaan dan produk yang dihasilkan oleh perusahaan tersebut, sehingga perusahaan tidak perlu lagi untuk mempromosikan produknya melalui reklame dan memilih membuat SIUP untuk memperlancar kegiatan usahanya.

PDRB disini dapat menjadi variabel moderasi yang memperbesar pengaruh jumlah SIUP terhadap penerimaan pajak reklame. Semakin tinggi nilai interaksi antara jumlah SIUP dan PDRB semakin tinggi pula pengaruh jumlah SIUP terhadap penerimaan pajak reklame.

\section{PENUTUP}

Simpulan
Berdasarkan hasil analisis yang telah dilakukan, maka dapat diambil kesimpulan sebagai berikut:

1. Jumlah penduduk tidak berpengaruh positif signifikan terhadap penerimaan pajak reklame.

2. Jumlah industri berpengaruh positif signifikan terhadap penerimaan pajak reklame.

3. Jumlah SIUP berpengaruh negatif signifikan terhadap penerimaan pajak reklame.

4. X1.Z tidak berpengaruh positif signifikan terhadap penerimaan pajak reklame dan PDRB memperlemah hubungan jumlah penduduk terhadap penerimaan pajak reklame.

5. X2.Z tidak berpengaruh negatif signifikan terhadap penerimaan pajak reklame dan PDRB memperlemah hubungan jumlah industri terhadap penerimaan pajak reklame.

6. X2.Z berpengaruh negatif signifikan terhadap penerimaan pajak reklame dan PDRB memperkuat hubungan jumlah SIUP terhadap penerimaan pajak reklame.

\section{Saran}

Berdasarkan hasil kesimpulan diatas, maka saran yang diberikan sebagai berikut :

7. Berdasarkan hasil penelitian varibel yang mempengaruhi penerimaan pajak reklame adalah jumlah industri dan jumlah SIUP. Maka dari itu pemerintah Kabupaten Magetan perlu menggalakkan program UMKM dengan jalan sosialisasi dan mengadakan pelatihan-pelatihan UMKM kepada seluruh masyarakat. Pemerintah juga harus mempermudah proses pembuatan SIUP bagi para pedagang agar jumlah Surat Ijin Usaha Perdagangan (SIUP) semakin meningkat yang pada 
akhirnya memudahkan para pelaku usaha untuk memasarkan produk dan mengembangkan usaha mereka.

8. Bagi peneliti selanjutnya agar menambah variabel lain yang mungkin mempengaruhi penerimaan pajak reklame. Selain itu peneliti juga dapat menambah obyek/sampel penelitian agar hasil penelitian lebih akurat.

\section{DAFTAR PUSTAKA}

Fatah, A. A., Suhadak, \& Hidayat, K. 2015. Pengaruh Jumlah Penduduk dan Jumlah Industri Terhadap Penerimaan Pajak Reklame dan Efeknya Pada Penerimaan Pajak Daerah, Malang: Universitas Brawijaya.

Fitriandi, P., Aryanto, Y., \& Priyono, A. P. 2016. Kompilasi Undang-Undang Perpajakan, Jakarta: Salemba Empat.

Ghazali, Imam. 2016. Aplikasi Analisis Multivariate dengan Program IBM SPSS 23 (Edisi 8). Semarang: Badan Penerbit Universitas Diponegoro.

Gujarati, Damodar N, \& Portner, Dawn C. Dasar-dasar Ekonometrika, Jakarta: Salemba Empat.

Ilyas, W. B., Burton, R. 2010. Hukum Pajak (Edisi 5), Jakarta: Salemba Empat.

Jenas, Alvioretta. 2013. Pengaruh Jumlah Penduduk, Jumlah Industri, dan Produk Domestik Regional Bruto (PDRB) Terhadap Penerimaan Pajak Reklame Sebagai Sumber Pendapatan Asli Daerah. Bandung: Universitas Widyatama.

Liberty, Setio Neo. 2013. Analisis FaktorFaktor yang Mempengaruhi Penerimaan Pajak Reklame di Kabupaten Jember, Jember: Universitas Jember.

Muljono, D., \& Wicaksono, B. 2009. Akuntansi Pajak Lanjutan. Yogyakarta: C.V Andi Offset.
Prasetyo, R. A., Masitoh, E., \& Dewi, R. 2017. Faktor-Faktor yang Mempengaruhi Penerimaan Pajak Reklame di Kabupaten Karanganyar, Surakarta: Universitas Islam Batik.

Priyatno, Duwi. 2010. Teknik Mudah dan Cepat Melakukan Analisis Data Penelitian dengan SPSS dan Tanya Jawab Ujian Pendadaran. Yogyakarta: Gava Media.

Putri, Phany Ineke. 2013. Faktor-Faktor yang Mempengaruhi Penerimaan Pajak, Semarang: Universitas Jenderal Soedirman.

Subroto, G. F., Harimurti, F., \& Suharno. 2016. Analisis Faktor-Faktor yang Mempengaruhi Penerimaan Pajak Reklame Kota Surakarta, Surakarta: Universitas Slamet Riyadi

Sugiyono. 2017. Metode Penelitian Kuantitatif,, Kualitatif, dan $R \& D$ (Cetakan Ke-25). Bandung: Alfabeta.

Sukirno, Sadono. 2012. Teori Pengantar Mikro Ekonomi (Edisi Ketiga), Jakarta: PT Raja Grafindo Persada.

Sutedi, Adrian. 2011. Hukum Pajak (Cetakan Pertama), Jakarta: Sinar Grafika.

Tristianto, Arisman, A., \& Fajriana, I. 2015. Pengaruh Jumlah Industri, PDRB, dan Pendapatan Per Kapita Terhadap Penerimaan Pajak Reklame Sebagai Pendapatan Asli Daerah Kota Palembang, Palembang: STIE MDP.

Utomo, Lisa Linawati. 1999. Economic Value Added Sebagai Ukuran Keberhasilan Kinerja Manajemen Perusahaan, Surabaya: Universitas Kristen Petra.

Wahdi, N., Saifudin, \& Wijayanti, R. 2015. Analisis Penerimaan Pajak Reklame di Kota Semarang, Semarang: Universitas Semarang. 
Yogyandaru, S. W., \& Sumantri, Edi. 2013. Analisis Pengaruh Faktor Ekonomi Terhadap Penerimaan
Pajak Reklame di DKI Jakarta Selama Tahun 2006-2010, Jakarta: $\quad$ FISIP UI 